\title{
STUDI TENTANG PARTISIPASI PEREMPUAN DALAM PENGAMBILAN KEPUTUSAN MUSYAWARAH LEO DI KABUPATEN ROTE NDAO
}

\author{
Kiki Else Dorline Tulle \\ Program Pascasarjana, Universitas Nusa Cendana Kupang, kikielsedorline.tulle@yahoo.co.id
}

DOI: 10.17510/paradigma.v6i1.81.

\begin{abstract}
Women participation in decision making is a manifestation of equality between men and women. Public arena is dominated by men meanwhile the women were put mainly only on domestic domain and almost didn't have any access to the public arena. Main issue of this research was the women participation in decision making in Leo discussion at Rote Ndao district. This was a descriptive qualitative research with phenomenological and cultural approaches. Data collection techniques used were interview with informants, observation and document analysis. From this research it was known that the women participation in Leo discussion was limited only on giving comments and advices, final decision was then made by the male, because tradition said that men had the rights on decision making. Although still dominated by men, there were some women participation in Leo discussion, women could made decision which related to technical means issues in Leo discussion. Public area were still dominated by men and its domestic counterparts were still fully done by the womens. Women were heard if they were highly educated, women were respected when they were experienced, oldest, had life character which put in high regard, not arrogant, motherly, mildly resolute, and used to public appearances.
\end{abstract}

\section{KEYWORDS}

Women participation; decision making; Leo discussion.

\section{Pendahuluan}

Peran gender di berbagai kebijakan berakibat domestikasi, marginalisasi, eksploitasi ekonomi, beban ganda, dan subordinasi seksual. Isi kebijakan tampaknya menyatakan perlindungan bagi perempuan dan persamaan sebagai mitra sejajar dalam pembangunan, dalam kenyataan antara perempuan sebagai mitra sejajar dengan laki-laki dalam segala bidang masih ada penyimpangan terselubung yang memosisikan perempuan di tempat kedua setelah laki-laki (Isnaeni, 2004). 
Laki-laki menguasai arena publik, sedangkan perempuan hanya berkutat di wilayah domestik yang hampir tidak memiliki akses politis. Dalam hubungan antara laki-laki dan perempuan, konstruksi sosial telah menempatkan kodrat, nilai-nilai, adat istiadat sebagai sarana untuk membentuk suatu hubungan sosial yang sangat timpang. Ketimpangan itu terjadi karena dalam setiap aspek kehidupan, male value lebih dihargai dibanding dengan female value yang telah tersubordinasi oleh kekuasaan (Isnaeni, 2004).

Perempuan dalam aktivitasnya yang terbatas dapat dilihat dari sedikitnya ta perempuan di anggota Dewan Perwakilan Rakyat Republik Indonesia: 79 orang (14\%). Nusa Tenggara Timur pun tidak mempunyai perwakilan perempuan di Senayan, bahkan di Kabupaten Rote Ndao hanya satu orang yang terpilih menjadi anggota DPRD, sangat kurang dari yang telah ditetapkan.

Aktivitas perempuan di Rote sangat terbatas, bahkan tidak ada tokoh perempuan di Kabupaten Rote Ndao. Secara keseluruhan, perempuan di Rote sangat terbatas dalam pembuatan kebijakan dan posisi kepemimpinan karenakondisi sosial budaya yang mempersulit perempuan untuk terlibat secara penuh di dalamnya. Tingkat pendidikan perempuan yang pada umumnya rendah, serta faktor kemiskinan semakin memperburuk permasalahan. Makin banyak perempuan yang tidak peduli akan hak politis mereka. Dalam situasi mayoritas laki-laki tidak menyadari pentingnya kesetaraan dan partisipasi perempuan, serta rendahnya dukungan sosial dan keluarga, perempuan semakin sulit untuk mengatakan tidak mungkin terlibat dunia politis (Ratoe Oedjoe, 2011).

Di dalam sistem kekerabatan, orang Rote lebih menghargai dan mengutamakan kedudukan lakilaki, seorang istri dilepaskan dari hubungan kekeluargaan dengan orang tuanya, nenek moyangnya, saudara sekandung, saudara sepupu, dan keluarga lain. Sejak menikah, istri masuk dalam lingkungan keluarga suaminya, begitu pun anak hasil perkawinannya. Hal ini dipengaruhi oleh budaya patriarki yang mengakar dalam sistem politis yang didominasi oleh laki-laki. Itu berdampak negatif besar pada upaya perempuan untuk mendapatkan hak dalam partisipasi politisnya. Perempuan tidak didukung, bahkan dalam banyak hal dihambat, untuk mengambil peran aktif di ruang publik. Sebaliknya, perempuan diharapkan untuk menggunakan kemampuannya di lingkungan rumah tangga yang dianggap sebagai ruang privat.

Pola struktur masyarakat Rote bersifat patrilineal-patrilokal, artinya relasi kekeluargaan dihitung menurut garis keturunan ayah dan anggota keluarga bernaung di bawah payung ayah. Hubungan kekerabatan masyarakat Rote mulai dari subetnis (mendiami sebuah wilayah yang disebut nusak), kemudian subetnis terbagi dari beberapa klen (leo). Leo adalah sekelompok masyarakat yang terdiri dari keluarga 
batih yang lahir dari suatu keturunan tertentu, leo dapat disamakan dengan marga dari tiap-tiap leo dipilih seorang untuk menduduki jabatan manesio (jabatan fungsionaris) yang mewakili leo yang bersangkutan dalam sistem atau struktur pemerintahan nusak atau kerajaan. Jabatan yang mewakili setiap jabatan disebut maneleo sehingga, apabila mewakili leo Modok, ia disebut manemodok dan seterusnya.

Setiap marga merupakan suatu keluarga yang merasa senasib dan sepenanggungan. Apabila timbul masalah dalam marga atau leo, anggotanya wajib menanggungnya secara bergotong royong. Marga dapat menghadapi baik masalah pembayaran mas kawin atau belis (pembayaran mas kawin), maupun biaya pesta nikah, kematian, serta membangun rumah baru, pertanian, dan kemakmuran (Soh dan Indrayana, 2008). Sistem kekerabatan patrilineal yang dianut membuat perempuan memiliki derajat yang lebih rendah dan diabaikan, perempuan dianggap dan disetarakan dengan anak-anak, maka tidak diperkenankan ikut dalam musyawarah yang dilakukan leo yang terbentuk dari hubungan darah dan daging di Rote.

Perempuan Rote kurang mendapat tempat karena masyarakat Rote yang tergabung di dalam leo masih mengganggap laki-laki mempunyai derajat yang lebih tinggi dibandingkan perempuan. Sebagai contoh, dalam pembagian warisan tanah, rumah, ternak, kebun buah-buahan, dan sawah, hanya anak laki-laki yang berhak, sedangkan bagi anak perempuan hanya mendapatkan perabotan rumah tangga dan perhiasan. Pada acara makan bersama, sudah menjadi kebiasaan bahwa suami dan istri tidak makan bersama-sama. Suami harus makan terlebih dahulu dan istri bertugas melayani suami (Soh dan Indrayana, 2008). Keadaan itu membuat perempuan di Rote tertinggal sehingga kesetaraan dan keadilan gender (KKG) antara laki-laki dan perempuan di Rote lambat terwujud.

Perempuan juga memilik hak dalam berpolitik termasuk dalam pengambilan keputusan baik dalam musyawarah adat maupun dalam pemerintahan, tetapi yang terjadi di Rote adalah sebaliknya: perempuan tidak diperkenankan hadir dalam setiap pengambilan keputusan dalam musyawarah leo. Berdasarkan uraian di atas, dapat dirumuskan permasalahan penelitian: pengaruh budaya pada peran perempuan dalam masyarakat Rote. Permasalahan itu diperinci sebagai berikut. Apa posisi, peran, dan tugas perempuan dalam pandangan adat Rote? Bagaimana pembagian peran dan tugas perempuan dan laki-laki Rote dalam kegiatan domestik ataupun publik? Bagaimana partisipasi perempuan dalam pengambilan keputusan musyawarah leo? Apa faktor yang memengaruhi partisipasi perempuan dalam pengambilan keputusan musyawarah leo? 


\section{Metodologi Penelitian}

Penelitian mengenai partisipasi perempuan dalam pengambilan keputusan musyawarah leo ini berancangan kualitatif, fenomenologis, dan budaya yang menekankan pada pengalaman subjektif manusia dan interpretasi manusia. Peneliti ini berusaha memahami arti peristiwa dalam pengambilan keputusan musyawarah leo, partisipasi perempuan dalam pengambilan keputusan dan kaitannya dengan anggota musyawarah leo. Teknik pengumpulan data yang digunakan dalam penelitian ini adalah wawancara, observasi, dan studi dokumen.

\section{Analisis dan Diskusi}

Kata leo berasal dari bahasa daerah Rote yang artinya kumpulan marga atau klan. Marga atau klan yang sejak zaman nenek moyang hingga sekarang tergabung dalam leo itu masih berhubungan darah. Leo terdiri atas dua bagian yaitu maneleo dan analeo. Maneleo berasal dari kata manek yang artinya raja, maka maneleo dianggap sebagai raja dalam leo itu. Maneleo dipilih oleh suara terbanyak analeo (anggota/marga yang tergabung dalam leo). Setelah melakukan pemilihan, maneleo dikukuhkan oleh bupati, atau dapat dimandatkan ke camat untuk mengukuhkan menjadi maneleo. Berdasarkan tinggi jabatan seorang maneleo atau raja dalam klan tertentu, maneleo terdiri atas beberapa bagian yaitu Maneleoinahuk atau maneleo besar yang menjabat sebagai maneleo kabupaten. Maneleo kecamatan yang menjabat sebagai maneleo kecamatan. Maneleo desa/kelurahan yang menjabat sebagai maneleo desa atau kelurahan.

Maneleoinahuk (besar) yang merupakan maneleo kabupaten dipilih oleh maneleo kecamatan dan desa/kelurahan. Peran maneleoinahuk bersifat koordinatif, mengarahkan, melindungi. Maneleo kacamatan dipilih oleh para maneleo desa/kelurahan, sedangkan maneleo desa/kelurahan dipilih oleh analeo yaitu anggota masyarakat yang dituakan, yang berhubungan dengan leo itu. Dalam sistem perkawinan, pantang terjadi perkawinan di antara anggota yang berada di dalam satu marga. Perkawinan di dalam satu marga yang satu leo, akan mendatangkan bencana bagi yang bersangkutan dan seluruh keluarganya. Keluarga itu dianggap tidak bersih lagi di mata semua anggota marga atau leo ataupun leo-leo lain (Soh dan Indrayana, 2008).

Dijelaskan dalam wawancara Alex Tulle, Kamis 07 April 2016 pukul 14.00-16.00, bahwa seorang maneleo adalah orang yang dianggap sangat mengetahui cerita semua marga, termasuk di dalamnya asal usulnya serta semua analeo. Adapun kriteria figur maneleo cukup banyak: (a) kepribadian yang baik, (b) 
berwibawa, (c) cakap, (d) berani tampil dan bertindak, (e) tegas, (f) kekeluargaan yang tinggi, (g) tidak sombong, (h) dituakan, (i) merasa memiliki analeo, dan (j) berjiwa sosial.

Pendukung utama seorang maneleo adalah istri yang disebut inaleo (istri maneleo) yang kriterianya adalah (a) berkepribadian baik, (b) cakap dan tegas, (c) kekeluargaan yang tinggi, (d) tidak sombong, (e) merasa memiliki analeo, (f) berjiwa social, dan ( $\mathrm{g}$ ) berani tampil dan bertindak.

Tugas utama maneleo adalah selalu hadir baik dalam suasana suka maupun duka yang dihadapi analeo, menyelesaikan masalah intern leo, artinya perkara yang melibatkan leo akan diselesaikan hingga tuntas; memberikan sambutan saat kematian, pernikahan dan acara resmi lain, mewakili leo dalam kegiatan adat, upacara kemasyarakatan di desa/kelurahan, kecamatan dan kabupaten, menghadiri acara lain apabila dibutuhkan, sedangkan istri maneleo bertugas mendampingi suami (maneleo) dalam semua kegiatan maneleo. la bertindak dan memberikan saran atau usul mengenai pekerjaan perempuan dalam acara kematian, pernikahan, acara adat, dan lain. Jabatan maneleo merupakan jabatan yang bergengsi, berwibawa, dan jabatan sosial sehingga istri maneleo harus siap membantu mengeluarkan sejumlah dana atau biaya untuk melengkapi kekurangan. Dijelaskan oleh Alex Tulle lebih lanjut dalam wawancara bahwa manfaat leo yakni tidak terjadi kawin-mawin di antara sesama leo; karena adanya hubungan darah, tidak mudah bermusuhan; karena hubungan kekerabatan, tidak ada sabotase leo lain; rasa persaudaraan dan kekerabatan yang tinggi membantu memberikan dana pendidikan analeo, membantu menyejaterahkan analeo, memberikan bantuan dana kesehatan.

Maneleo sebagai pemimpin didampingi oleh leo fetor yang merupakan jabatan kehormatan untuk keluarga istri maneleo. Manek dan fetor hanya dibedakan dalam pembagian tugas dan fungsi. Tugas maneleo menyelesaikan urusan yang bersifat spiritual dan fetor khusus urusan duniawi, tugas maneleo antara lain mengatur kerja gotong royong, tu, ubelis (mengangkat belis) pesta nikah, kematian, membangun rumah, pesta adat, pertanian, dan kemakmuran. Pembantu maneleo adalah manesiolangga yang mengkoordinasi suatu wilayah tertentu. Pada tingkat leo, suatu maneleo bertugas khusus sebagai pengayoman terhadap leo. Tugas mengurus tanah diserahkan kepada daelangga, sedangkan imam upacara disebut manesonggo dan utusan peradilan disebut manedope (Soh dan Indrayana, 2008)

Menurut Thobias Pingak dalam wawancara, Senin 11 April 2016 pukul 20.00-21.30, kekurangan leo atau kumpulan marga adalah pembatasan antarmarga atau pembatasan anggota leo dengan anggota leo 
lain, kurangnya rasa kekeluargaan antaranggota masyarakat dan antar-leo, kurangnya perhatian maneleo pada analeo atau anggota marga.

\section{Posisi, Peran, dan Tugas Perempuan Rote dalam Pandangan Adat Rote}

Posisi, peran, dan tugas perempuan Rote dalam pandangan adat Rote pada masa lalu dan sekarang berbeda. Contoh: dalam hal makan bersama, pada masa lalu kebiasaannya adalah suami istri tidak makan bersama. Pada waktu makan siang suami harus terlebih dahulu, istri bertugas melayani suami, mulai dari menyiapkan makanan hingga selesai makan. Alasan utama membedakan waktu makan ialah menjaga kemungkinan mereka kedatangan tamu. Suami dan istri itu dikatakan tidak sopan jika membiarkan tamu duduk sendiri, tanpa ditemani, dan menunggu sampai suami istri selesai makan. Sudah menjadi kebiasaan pula bahwa suami harus dihormati karena dialah yang menjadi pelindung keluarganya. Suami sebagai kepala keluarga perlu dijunjung tinggi karena ia menanggung beban paling berat dan tanggung jawab dalam hal memenuhi kebutuhan keluarganya atau mencari nafkah. Sistem itu tercermin dalam ungkapan mana tungga sangga (mencari) sehingga dalam banyak hal suamilah yang di istimewakan. Jika mereka kedatangan tamu dan harus makan bersama, istrilah yang harus melayani suami dan tamu. Istri akan makan setelah mereka selesai makan.

Pada waktu tertentu, suami juga ingin menghormati istrinya dengan cara makan bersama. Dasarnya adalah istri adalah seorang yang disayangi dan dengan tabah mendampingi dan melayaninya setiap hari dalam memenuhi segala keperluannya. Jadi, istri merupakan pelengkap di mata suaminya; tanpa istri, hidupnya tidak sempurna. Apabila suami istri sedang bepergian untuk melakukan suatu pekerjaan di kebun, sebelum jam atau waktu makan, istri harus pulang terlebih dahulu untuk menyiapkan makanan. Namun, dalam keadaan yang tidak mengizinkan, mereka pulang bersama. Setelah tiba dirumah, istri harus melakukan tugasnya menanak nasi dan menyiapkan segala keperluannya.

Dalam pekerjaan sudah lazim ada pembagian tugas antara laki-laki dan perempuan di samping pekerjaan rumah tangga yang harus dikerjakan setiap hari. Pada suku Rote, terutama dalam pekerjaan utama sebagai penyadap lontar, perempuan atau istri bertugas memasak nira hingga menjadi gula. Bila mempunyai sawah atau ladang, pekerjaan menanam dan menyiangi dilakukan oleh perempuan, suaminya yang menebang pohon, membuat pagar, dan membajak. Pekerjaan yang akan dilakukan esok harinya sudah mereka rencanakan pada malam hari sebelum tidur sehingga masing-masing telah mengetahui di 
mana mereka berada. Tujuannya adalah, bila suami perlu bertemu dengan istrinya, ia tidak sulit mencarinya demikian pula sebaliknya.

Suami istri itu melakukan pekerjaan bersama-sama. Misalnya di sawah suamilah yang membajak dan membuat pematang, sedangkan istrinya menanam. Dalam melaksakan tugas ini mereka tidak saling berbicara atau mengobrol. Mereka akan bercakap-cakap saat jam makan, tetapi dilakukan dengan tergesagesa karena adanya pantangan di kalangan mereka. Bekerja sambil mengobrol, menurut kepercayaan suku Rote, akan membawa akibat yang tidak diinginkan, misalnya tanaman tidak akan memberi hasil sebagaimana diharapkan. Akan tetapi, ada juga pekerjaan yang harus dilakukan bersama-sama. Di sini dapat dilihat peran suami istri dalam kedudukannya sebagai kepala rumah tangga atau kepala keluarga. Sang istri dengan setia menuruti perintah suami tanpa membantah sedikit pun.

Pergaulan antara suami dan istri dalam keluarga juga mengikuti kebiasaan. Kedudukan suami atau ayah dalam suatu keluarga adalah kepala rumah tangga dan pelindung istrinya. Oleh karena itu, di dalam pergaulan sehari-hari, baik di dalam maupun di luar rumah, istri tetap menganggap suaminya sebagai seorang yang lebih tinggi statusnya dan mempunyai kuasa. Di dalam pergaulan hidup bersama, ada saat-saat suami atau istri pergi sementara meninggalkan rumah. Misalnya pergi untuk mencari nafkah, menghadiri acara keluarga atau tugas sosial lain. Maka salah satu akan memberitahukan atau memberi salam kepada lainnnya sebagai tanda bahwa ia akan pergi (Soh dan Indrayana, 2008).

Sampai sini dalam kegiatan upacara baik itu upacara adat ataupun upacara yang bersifat keagamaan atau kepercayaan biasanya dihadiri oleh suami dan istri bersama-sama. Pada waktu pergi untuk menghadiri maupun pada waktu pulang mereka berjalan beriringan, biasanya perempuan berjalan terlebih dahulu biasanya suami menyapa istri dengan sapaan oo maka huluk yang artinya engkau berjalan di depan, atau langsung saja dengan kata makahuluk yang artinya berjalan di depan. Suami sebagai pengawal, pelindung terhadap istri adalah wajib dari belakang maka bahaya itu dapat dihalangi oleh suami.

Suatu keadaan yang tidak dikehendaki dari arah depan mudah dilihat dan diamati oleh sang suami atau apabila datangnya dari belakang maka bahaya itu dapat dihalangi oleh suami. Setelah tiba ditempat upacara terjadi pengelompokan antara laki-laki dan perempuan, sehingga suami istri harus duduk terpisah sesuai dengan tingkatan yang ada dalam masyarakat (Soh dan Indrayana, 2008). Dalam adat orang Rote dimasa lalu ketika melakukan ritual adat berhubungan dengan kepercayaan terdapat pembagian peran laki-laki dan perempuan. Tugas perempuan menyiapkan sarana upacara, seperti memasak makanan, 
menyiapkan sajian untuk laki-laki yang akan menjalankan ritual. Tugas perempuan hanyalah membantu dalam proses upacara keagamaan. Yang melakukan hubungan secara langsung dengan Tuhan hanyalah laki-laki.

Dalamurusan pernikahan, perempuan menyiapkan perlengkapan yang berkaitan dengan peminangan hingga pada pesta pernikahan. Perempuan menyiapkan secara detail dan menyeluruh perlengkapan yang dibutuhkan dalam pesta pernikahan, peran perempuan Rote diperkuat dengan tuturan adat tou bala sesele dan ina bala lulutu artinya peran laki-laki kasar atau hanya bersifat umum, perempuan berperan secara detail, hingga pada hal-hal kecil seperti dulang dan isinya untuk meminang, alat masak, bahan masak, pakaian yang digunakan oleh pengantin laki-laki dan perempuan, perempuan juga mempunyai peran dalam acara "simpan peti" dimana setiap perempuan yang datang harus membawa selimut ataupun alat-alat rumah tangga seperti kain meja, seprei, alat makan, alat masak, untuk diberikan pada calon pengantin perempuan. Hal adat akan dibicarakan oleh laki-laki seperti jumlah belis, to'ok (biaya yang diberikan untuk saudara laki-laki dari mama) dan anggaran pernikahan. Perempuan juga dapat hadir dalam pengambilan keputusan jumlah belis, to'ok dan anggaran pernikahan, memberikan usul dan saran, tetapi laki-laki lebih berperan dan laki-laki bertindak sebagai pengambil keputusan.

Pada upacara adat kematian kehadiran perempuan dari pagi hingga malam hari, perempuan mengurus saat seseorang meninggal hingga dimakakamkan, bukan saja mengurus orang yang telah meninggal, bahkan perempuan lebih merasakan duka yang dalam, hal ini berdasarkan observasi yang dilakukan peneliti ini, sejalan dengan penjelasan dari Arkhymes Molle yang mengatakan:

\footnotetext{
Kalau berhubungan dengan kematian perempuan Rote sangat berperan karena dia mulai mengurus dari orang itu meninggal sampai orang itu dimakamkan, ia bukan saja mengurus orang yang meninggal tetapi ia juga lebih dalam merasakan peristiwa kematian dibandingkan laki-laki. Perempuan menyiapkan segala sesuatu dari merawat jenazah itu, hingga pada acara pemakaman, termasuk pesta atau syukuran kematian, makan, minum juga termasuk peran perempuan, jadi sebenarnya laki-laki hanya duduk.
}

Perempuan yang tergabung dalam leo sudah mengetahui dan mengerti akan tugas dan pekerjaan yang harus dilakukan tanpa mendapat perintah orang lain yaitu sumbang-menyumbang uang, makanan berupa padi, beras, dan hewan dalam kegiatan leo contoh tugas perempuan dalam kematian, menyediakan selimut adat untuk diberikan pada tamu yang datang, sebelumnya tamu itu pernah memberi selimut adat kepada tuan pesta. Ini merupakan selimut adat yang harus diberikan pada tamu sebagai balasan selimut 
yang pernah diterima, akan tetapi Arkhymes Molle dalam wawancara pada Kamis, 03 Maret 2016 pada pukul 18.00-21.00 mengatakan bahwa posisi perempuan dalam kematian pada tempat nomor dua.

Dari penjelasan diatas memiliki makna bahwa posisi, peran dan tugas perempuan dalam pandangan adat Rote belum jauh berbeda dengan masa lalu, perempuan masih ada pada posisi kedua dalam acara adat, hanya mempunyai peran dan tugas dalam menyiapkan sarana untuk acara adat, seperti adat pernikahan, kematian.

\section{Pembagian Peran dan Tugas Laki-Laki dan Perempuan Rote}

Tugas produktif yang biasa dilakukan laki-laki Rote dibantu oleh perempuan. Banyak peran perempuan didalamnya, mulai dari mencari kayu bakar, hingga mengolah nira menjadi gula dilakukan oleh perempuan. Laki-laki dan perempuan Rote berbagi peran dan tugas sesuai kemampuannya.

Pembagian peran dan tugas perempuan dan laki-laki Rote dilakukan sesuai kemampuan, karena adanya pekerjaan yang tidak mampu dilakukan oleh perempuan, contoh mengambil nira dilakukan oleh lakilaki karena perempuan tidak dapat memanjat pohon. Laki-laki memacul sawah, membuat pagar di ladang, jika perempuan melakukan hal-hal yang dikerjakan oleh laki-laki maka laki-laki dianggap tidak memiliki wibawa karena membiarkan perempuan bekerja pekerjaan yang seharusnya dilakukan laki-laki.

Dalam suatu pesta adat, adanya pembagian tugas antara laki-laki dan perempuan agar terselenggara pesta dengan baik, laki-laki membunuh hewan, membersihkan, dan perempuan memasak, menyiapkan alat masak dan alat makan. Dalam melayani pun laki-laki dan perempuan secara bersama-sama yakni perempuan membawa nasi dan laki-laki membawa daging untuk diambil oleh tamu undangan. Danjte Ndun selaku maneleo Forum Adat Kecamatan Lobalain dalam wawancara pada Sabtu 16 April 2016 pukul 16.0018.00 mengatakan bahwa laki-laki dan perempuan Rote secara bersama-sama mencari nafkah, perempuan tidak dibatasi untuk melakukan kegiatan yang dapat meningkatkan tingkat ekonomi keluarga akan tetapi mengurus anak-anak di Rote masih lebih banyak dibebankan kepada ibu atau perempuan seperti memasak, dan mencuci dan menjaga anak. Laki-laki Rote masih mengganggap bahwa mengurus anak merupakan tugas utama seorang ibu.

Urusan produktif dan reproduktif lebih banyak beban kepada perempuan tetapi ada pula di antara masyarakat Rote yang berbagi peran dan tugas produktif, seperti di Ndao yang mayoritas penduduknya bermatapencaharian sebagai penenun bukan saja dilakukan oleh perempuan, tetapi laki-laki juga dapat 
membantu istrinya menenun. Biasanya perempuan menenun dan laki-laki menjual hasil tenunan, masyarakat Pulau Ndao dapat saling membantu dan dapat berganti peran yakni laki-laki dan perempuan menenun secara bersama-sama dan perempuan menjual ke luar Pulau Ndao. Hal ini berarti sudah diterapkannya peran gender dimana laki-laki dan perempuan dapat berganti peran, walaupun belum secara keseluruhan diterapkan oleh masyarakat di Rote Ndao seperti yang juga dijelaskan oleh Leonard Haning yang mengatakan: "Laki-laki dan perempuan Rote dapat berganti peran, laki-laki dapat masuk dalam area domestik dan perempuan masuk ke area publik laki-laki".

Hasil tenun yang sudah dibuat oleh perempuan Rote kemudian dipasarkan oleh laki-laki ke luar daerah seperti ke Ba'a, Kupang atau di kota-kota lain di Nusa Tenggara Timur. Laki-laki di Pulau Ndao pergi ke luar daerah untuk menjual hasil tenunan selama 6 hingga 7 bulan lamanya dari bulan Maret hingga November. Ketika laki-laki pulang membawa hasil jual tenun ikat, pending, bulamolik dan beras untuk kebutuhan 1 tahun lamanya karena transportasi ke Pulau Ndao tidak lancar sehingga laki-laki di Ndao pulang harus membawa kebutuhan beras untuk 1 tahun lamanya. Sementara laki-laki ke luar daerah, perempuan mengatur kehidupan anak-anaknya dan segala urusan domestik perempuan.

Perempuan Rote dalam perkembangannya diberikan kesempatan untuk memberi peran di dunia publik yang dahulu lebih banyak dikuasai oleh laki-laki, tetapi tidak semua perempuan Rote mendapat kesempatan itu, jika diberikan kesempatan untuk masuk ke areah publik sedikit diantara mereka menggunakan kesempatan itu, hal ini sejalan dengan penjelasan dari Thobias Pingak yang mengatakan : "Sudah ada peluang diberikan kepada perempuan tetapi karena terikat dengan tradisi perempuan pun masih takut".

Kesempatan yang kurang dimanfaatkan oleh perempuan Rote tampil ke area publik karena adanya peran ganda yang harus dilakukan perempuan yaitu melahirkan dan menyusui, dan mengurus rumah tangga, faktor fisik yang tidak begitu kuat dan perempuan merasa tidak mampu masuk ke area publik. Berdasarkan wawancara dengan Leonard Haning dari leo Todefeo sebagai maneleo induk (inahuk) di Kabupaten Rote Ndao pada Selasa, 08 Maret 2016 pada pukul 9.00-10.00 mengatakan bahwa perempuan Rote dapat menjadi pemimpin yaitu pemimpin bagi dirinya sendiri dan keluarga, sedangkan laki-laki adalah kepala keluarga. Adanya pembagian tugas dan peran antara laki-laki dan perempuan Rote yakni perempuan Rote pada tugas dan peran yang lembut, ringan dan halus sedangkan laki-laki pada tugas yang berat dan kasar.

Hal ini membuat perempuan lebih banyak memberi peran pada dunia domestik, dan tidak mau melibatkan diri dalam urusan publik. Pekerjaan domestik seperti mencuci, membersihkan rumah, memasak, 
dan mengasuh anak dianggap merupakan tugas utama perempuan yang bersifat halus dan ringan, sedangkan dunia publik yang membutuhkan keterampilan dan potensi khusus dikontruksikan menjadi bagian laki-laki. Hal inilah yang menjadi pemikiran perempuan Rote sehingga dapat dilihat secara nyata dalam tabel 1 , pembagian tugas dan peran laki-laki dan perempuan yakni laki-laki memiliki hak penuh dalam hubungan dengan publik dan perempuan berhubungan dengan dunia domestik.

\begin{tabular}{|c|c|c|c|}
\hline No & Musyawarah Leo & Laki-laki & Perempuan \\
\hline 1. & Perkawinan & $\begin{array}{l}\text { Membicarakan adat seperti belis, } \\
\text { jenis hewan yang dibutuhkan. } \\
\text { Mengundang keluarga untuk hadir } \\
\text { dalam pesta perkawinan. } \\
\text { Membawa lampu pada saat } \\
\text { meminang. } \\
\text { Menjadi juru bicara dalam } \\
\text { peminangan. } \\
\text { Membangun tenda. } \\
\text { Membunuh hewan. }\end{array}$ & $\begin{array}{l}\text { Menyiapkan dulang dan isi dulang } \\
\text { yang diminta keluarga perempuan } \\
\text { untuk meminang, } \\
\text { Membawa dulang yang berisi } \\
\text { antaran untuk perempuan } \\
\text { Merias calon pengantin. } \\
\text { Menyiapkan alat masak. } \\
\text { Mengumpulkan tenaga kerja untuk } \\
\text { masak } \\
\text { Memasak untuk kebutuhan pesta } \\
\text { perkawinan. }\end{array}$ \\
\hline 2. & Kematian & $\begin{array}{l}\text { Memberitahukan kepada keluarga } \\
\text { (analeo) berita kematian dan } \\
\text { pengucapan syukur. } \\
\text { Menyiapkan peti dan lubang untuk } \\
\text { penguburan } \\
\text { Menentukan waktu penguburan } \\
\text { dan syukuran kematian. } \\
\text { Menentukan keluarga yang } \\
\text { diundang dalam syukuran } \\
\text { kematian. } \\
\text { Menentukan jenis hewan apa yang } \\
\text { dibunuh dan bagaimana caranya } \\
\text { membunuh. } \\
\text { Menyiapkan tenda. }\end{array}$ & $\begin{array}{l}\text { Menyiapkan pakaian orang yang } \\
\text { meninggal } \\
\text { Ruangan untuk pembaringan } \\
\text { orang yang meninggal. } \\
\text { Mengurus atau menanak nasi } \\
\text { untuk syukuran. } \\
\text { Mengumpulkan tenaga kerja untuk } \\
\text { masak. } \\
\text { Menghitung persediaan makanan } \\
\text { dengan jumlah undangan yang } \\
\text { ada. }\end{array}$ \\
\hline 3. & Pembangunan rumah & $\begin{array}{l}\text { Memotong kayu lontar untuk } \\
\text { membuat rangka rumah. } \\
\text { Memotong daun lontar untuk atap } \\
\text { rumah. } \\
\text { Mencari bebak (kayu) untuk } \\
\text { dinding rumah. }\end{array}$ & $\begin{array}{l}\text { Menyiapkan makanan untuk laki- } \\
\text { laki yang membangun rumah. } \\
\text { Membawa daun yang telah } \\
\text { dipotong oleh laki-laki. } \\
\text { Membawa dinding rumah untuk } \\
\text { dipasang oleh laki-laki. }\end{array}$ \\
\hline
\end{tabular}

Sumber: Wawancara dan diolah oleh Peneliti ini.

Tabel 1. Pembagian Tugas Laki-Laki Dan Perempuan Dalam Musyawarah Leo.

Pembagian beban kerja yang lebih banyak juga diberikan pada perempuan Rote dapat dilihat pada tabel 2, perempuan harus melakukan peran ganda, selain melakukan peran di area domestik dan 
reproduktif ia juga harus membantu laki-laki dalam peran produktif laki-laki sebagai kepala keluarga yakni harus mamasak nira menjadi gula dan kemudian memasarkannya, membantu laki-laki dalam mendapatkan minyak kelapa, kerja kebun, tenun ikat, pandai perak.

\begin{tabular}{|c|c|c|c|}
\hline & Jenis Pekerjaan & Laki-laki & Perempuan \\
\hline \multirow[t]{5}{*}{ Produktif } & Memasak gula & $\begin{array}{l}\text { Mengiris tuak (mengambil } \\
\text { nira dari pohon lontar). }\end{array}$ & $\begin{array}{l}\text { Memikul tuak/nira yang di } \\
\text { bawah laki-laki. } \\
\text { Mencari kayu bakar. } \\
\text { Memasak nira menjadi } \\
\text { gula. } \\
\text { Menjualnya. }\end{array}$ \\
\hline & Memasak minyak kelapa & $\begin{array}{l}\text { Memotong kelapa. } \\
\text { Memarut. } \\
\text { Meremas sari kelapa. }\end{array}$ & $\begin{array}{l}\text { Memarut kelapa. } \\
\text { Meremas sari kelapa. } \\
\text { Memasak minyak kelapa. } \\
\text { Menjual minyak kelapa. }\end{array}$ \\
\hline & Berkebun & $\begin{array}{l}\text { Memotong kayu untuk } \\
\text { membuat pagar. } \\
\text { Membuat pagar. } \\
\text { Memacul. } \\
\text { Membuat pematang. }\end{array}$ & $\begin{array}{l}\text { Mengangkat dan } \\
\text { memindahkan kayu yang } \\
\text { telah di potong ke lokasi } \\
\text { membuat pagar. } \\
\text { Membersihkan kebun. } \\
\text { Menanam benih. } \\
\text { Membersihkan rumput } \\
\text { disekitar tanaman. } \\
\text { Menyiram. } \\
\text { Penen. } \\
\text { Mengangkat hasil kebun } \\
\text { ke rumah. }\end{array}$ \\
\hline & Tenun ikat & Menjualnya ke luar daerah. & $\begin{array}{l}\text { Menenun dan mengikat } \\
\text { sarung dan selimut adat } \\
\text { Rote. }\end{array}$ \\
\hline & Pandai perak & $\begin{array}{l}\text { Membuat bulamolik } \\
\text { (hiasan kepala perempuan } \\
\text { pada pakaian adat Rote) } \\
\text { yang terbuat dari perak. } \\
\text { Membuat pending (ikat } \\
\text { pinggang yang dipakai } \\
\text { perempuan pada pakian } \\
\text { adat Rote). }\end{array}$ & $\begin{array}{l}\text { Memasak dan } \\
\text { menyediakan makanan } \\
\text { bagi laki-laki. }\end{array}$ \\
\hline Reproduktif & & & $\begin{array}{l}\text { Melahirkan. } \\
\text { Menyusui. }\end{array}$ \\
\hline
\end{tabular}

Sumber: Wawancara dan diolah oleh Peneliti ini.

Tabel 2. Pembagian Tugas Produktif Dan Reproduktif Laki-Laki Dan Perempuan Rote.

Berdasarkan penjelasan dan tabel di atas menunjukan laki-laki dan perempuan Rote mempunyai kesempatan yang sama di area publik, akan tetapi masih didominasi oleh laki-laki, karena adanya peran ganda yang harus dilakukan oleh perempuan dan faktor fisik yang membuat perempuan merasa tidak 
mampu bergelut di dunia publik, sedangkan area domestik perempuan masih secara penuh dilakukan oleh perempuan.

\section{Partisipasi Perempuan dalam Pengambilan Keputusan Musyawarah Leo}

Musyawarah leo dipimpin oleh maneleo, orang-orang yang hadir dalam musyawarah leo tergantung undangan, yaitu perwakilan dari analeo (marga-marga yang tergabung dalam leo). Masing-masing marga perwakilannya laki-laki dan membawa serta istrinya. Laki-laki dan perempuan duduk bersama akan tetapi perempuan akan berbicara ketika diminta, dan usul, saran perempuan tidak harus didengar. Perempuan Rote juga dapat memberi pendapat melalui tokoh-tokoh adat atau perwakilan dalam analeo dan jika pendapatnya itu positif maka perempuan sudah dianggap terlibat dalam pengambilan keputusan musyawarah leo.

Dimasa lalu dalam musyawarah leo perempuan diperkenankan memberi saran tetapi tempat duduknya pada sebelah barat, atau ekor meja, yang menduduki kepala meja atau dalam bahasa daerah Rote disebut mei langgak adalah laki-laki. Perempuan diperbolehkan berbicara atau memberi saran setelah laki-laki atau maneleo berbicara. Arkhyimes Molle, tokoh adat Dengka dalam wawancara mengatakan perempuan hadir dalam musyawarah akan tetapi diberikan kewenangan yang sifatnya terbatas. Perempuan (inaleo) hanya bersifat pendukung maneleo, inaleo (istri raja) tidak diberi hak untuk mengambil keputusan akhir dalam musyawarah leo karena perempuan Rote berada di bawah tekanan, dimana perempuan tidak diberi ruang secara leluasa dalam keputusan-keputusan adat, laki-laki mempunyai kewenangan yang sangat besar dalam pengambilan keputusan dalam musyawarah leo.

Dalam pengambilan keputusan faktor fisik, lingkungan dan status sosial seorang perempuan tidak mempunyai pengaruh dalam proses pengambilan keputusan musayawarah leo, karena laki-laki mempunyai kewenangan penuh dalam pengambilan keputusan. Pada upacara adat kematian, perempuan berada pada posisi kedua di bawah laki-laki, akan tetapi dalam pengambilan keputusan teknis upacara kematian ada pada tangan perempuan. Adanya perkembangan zaman yang menuntut adanya kesamaan perempuan dan laki-laki memang sudah diketahui orang Rote akan tetapi belum dilaksanakan secara maksimal, contoh belum adanya perempuan yang dipilih menjadi maneleo. Secara adat laki-laki Rote masih menganggap perempuan tidak boleh memerintah laki-laki dan memimpin laki-laki, hal ini membawa dampak minimnya peluang perempuan untuk menjadi pemimpin. 
Adat mengatur peranan perempuan tetapi bukan dalam hal pengambilan keputusan, karena didalam struktur adat perempuan mempunyai tugas pokok, dan fungsi tersendiri contoh tugas dari istri maneleo yaitu inaleo, dimana suami duduk di ruang depan maka peranan istri adalah mengurus segala sesuatu yang dibutuhkan suami bersama tokoh-tokoh adat. Secara tampilan inaleo tidak berperan seperti suaminya. Peranannya hanya terbatas pada hal-hal yang bersifat perempuan seperti pakaian adat, sirih pinang, karena bagi orang Rote, maneleo berarti manek yang artinya raja dan leo artinya suku maka maneleo adalah raja suku.

Istri dari kepala atau raja suku (maneleo) menyiapkan asesoris adat mulai dari pakaian adat dan makanan adat seperti sirih pinang, tetapi dalam pengambilan keputusan, maneleo atau suami lebih berperan, karena adanya tuturan adat touk manek, ina kakanak, yang berarti bahwa laki-laki adalah raja yang tampil untuk menegakan wibawa keluarga, perempuan tugasnya adalah mengurus anak dan keluarga. Dalam pengambilan keputusan perempuan dilibatkan tetapi dalam hal-hal tertentu yang bersifat perempuan. Perempuan dapat mengambil keputusan terakhir yang bersifat situasional dimana peserta musyawarah hanya dihadiri oleh perempuan, dan dalam organisasi perempuan, tetapi jika diantaranya terdapat laki-laki perempuan tidak dapat mengambil keputusan terakhir

Sebagian kecil leo-leo di Kabupaten Rote Ndao sudah memberikan akses dan peluang bagi perempuan untuk ikut dalam musyawarah leo karena dalam setiap pertemuan adat maneleo tidak pernah meninggalkan inaleo. Inaleotetap hadirdalam setiap pertemuan dan musyawarah adattetapi inaleo hanya pada posisi mendukung maneleo. Inaleo atau perempuan boleh memberikan alternatif, turut mempertimbangkan alternatif akan tetapi maneleo mempunyai otoritas dalam pengambilan keputusan terakhir.

Perempuan dapat memberikan pemikiran, dikarenakan istri atau perempuan lebih tahu hal yang dibutuhkan, maneleo pergaulannya terbatas, yang sering berkomunikasi dengan pihak luar adalah istri atau perempuan maka istri tahu hal yang harus disampaikan pada suami, istri atau perempuan menjadi pembisik suami, dari hal ini dapat dilihat bahwa perempuan melakukan empat tahapan dalam pengambilan keputusan yakni menilai informasi baru, melihat alternatif, mempertimbangkan alternatif, membuat komitmen (Janis dan Mann 1987) walaupun kemudian laki-laki sebagai pemegang keputusan terakhir.

Budaya patriarkhi yang menganggap laki-laki sebagai orang pertama seiring dengan kemajuan zaman dan ilmu pengetahuan mulai terkikis. Tokoh adat Dantje Ndun juga dalam wawancara Sabtu 16 
April 2016 pukul 16.00-18.00 mengemukakan bahwa dalam musyawarah leo saat ini juga diangkat masalah gender dimana perempuan dilibatkan dan didengar, terutama hal-hal yang berkaitan dengan perempuan.

Pergeseran budaya dimana dahulu lebih banyak penduduk laki-laki maka laki-laki harus menjadi pemimpin dan mendominasi acara adat tetapi kini perempuan di Rote telah diperkenankan untuk terlibat bersama dengan laki-laki dalam musyawarah leo, ini terbukti dari adanya keterlibatan perempuan dalam struktur organisasi kepengurusan leo, tetapi belum semua leo yang ada di Rote memasukan perempuan dalam struktur organisasinya, hanya sebagian kecil menganggap penting peranan perempuan, seperti struktur organisasi leo Lulu di Dengka. Dalam struktur perempuan berada pada posisi sekretaris, bendahara atau-pun jabatan lain selain sebagai maneleo atau raja suku.

Ketiadaan aturan yang melarang perempuan Rote menjadi pemimpin, akan tetapi belum adanya niat seorang perempuan. Perempuan diberikan kesempatan untuk menjadi pemimpin tetapi ditolaknya dengan alasan bahwa adanya laki-laki di tempat itu dapat menjadi pemimpin, pemimpin adalah pekerjaan yang berat, tidak mampu berkomunikasi dengan baik, takut, tidak percaya diri, tidak mampu membagi waktu dengan baik dengan keluarga (mengurus anak), contoh yang diberikan bahwa dalam pemilihan kepala desa di Keka, diberikan kesempatan pada salah satu perempuan yang ada pada desa itu, yang dianggap mampu berbicara dan mampu memimpin desa itu, dan berpendidikan tinggi yaitu SMA tetapi ia tidak menerima kesempatan itu karena terikat dengan tradisi dimana ia berpikir bahwa ada laki-laki yang bisa menjadi pemimpin. Masyarakat Keka menganggap laki-laki sebagai kepala, pemilik segala yang dimiliki, dan raja. Walaupun pernah mendengar perihal peran gender, peneliti ini belum meihat penerapannya di masyarakat Keka. Hingga sekarang menurut Thobias Pingak yang tergabung dalam leo Songa yag berasal dari Keka, bahwa belum ada perubahan yang besar partisipasi perempuan dalam adat, musyawarah leo, dan pengambilan keputusan yang harus diambil oleh laki-laki.

Berdasarkan wawancara dari analeo Thobias Pingakmengatakan bahwa di Keka didominasi oleh laki-laki, perempuan hanyalah diberi tugas pada jabatan seperti bendahara. la mengatakan bahwa dari dulu hingga sekarang perempuan di Keka tidak pernah tampil ke depan, karena adanya tradisi bahwa laki-laki harus menjadi pemimpin perempuan. Disambung oleh Thobias Pingak bahwa sesuatu yang memerlukan pengorbanan tidak boleh diputuskan oleh perempuan secara mandiri, seperti belis pada pernikahan, jika satu keluarga diberikan tanggungjawab menanggung atau membawa satu ekor hewan besar, perempuan tidak boleh secara langsung mengiyakan atau menyutujui hal itu, tetapi diperlukan diskusi antara suami 
dan istri. Jika suami setuju akan hal itu, akan diberikan kepada tuan pesta seekor hewan besar yang harus ditanggung oleh suami istri.

Perempuan menjadi orang kedua dalam musyawarah leo. Walaupun diberikan kesempatan untuk berbicara, perempuan diberi kesempatan kedua setelah laki-laki. Pada masyarakat Keka, dahulunya perempuan tak diperbolehkan menjadi pemimpin dalam organisasi kecil tetapi kini perempuan Keka pun diberikan kesempatan menjadi pemimpin meskipun kesempatan itu belum digunakan secara baik sehingga belum ada perempuan Keka yang menjadi pemimpin dalam organisasi kecil di Keka.

Anaci Panie-Otemusu, sebagai Ketua Pemberdayaan Perempuan dalam Adat Rote Ndao, mengatakan bahwa perempuan Rote sudah mulai berkembang menuju kesetaraan, tetapi peran gender belum seimbang dan masih didominasi oleh laki-laki. Pendapatnya sejalan dengan wawancara dengan analeo Marthen Luter Saek yang mengatakan

Ada partisipasi perempuan dalam tiap-tiap pertemuan adat seperti pernikahan dan perkawinan terlihat dari adanya keterlibatan dan kehadiran perempuan dalam musyawarah leo, akan tetapi dalam pengambilan keputusan sangat didominasi laki-laki, perempuan hanyalah mengambil keputusan secara hal-hal yang bersifat teknis.

Keaktifan berbicara juga lebih didominasi oleh laki-laki, perempuan diberi kesempatan bicara bilamana perlu. Perempuan hanya mengambil keputusan dalam urusan dapur pada sebuah pesta pernikahan ataupun acara adat lain. Perempuan dapat memberikan masukan mengenai hal-hal di luar masalah teknis (dapur, sarana) akan tetapi keputusan terakhir ada pada maneleo dalam hal ini adalah laki-laki, hal yang sama dijelaskan oleh Adrianus Tulle mengatakan:

Partisipasi perempuan dalam acara adat hanya mendukung dan menjalankan keputusan yang sudah dibuat maneleo bersama analeo. Peranan perempuan berada di belakang maneleo, status perempuan dalam musyawarah leo adalah hanya terbatas membantu suami atau meneleo, peranan perempuan hanyalah di belakang maneleo, pendapatnya yang berurusan dengan dapur, besar dana yang dibutuhkan dalam acara adat.

Dari semua informan mengatakan bahwa perempuan Rote mempunyai kesempatan besar untuk jadi pemimpin tetapi belum ada perempuan memimpin leo hingga sekarang ini. Sementara itu Jusuf Via menjelaskan dalam wawancara pada Senin, 11 April 2016 pukul 17.00-18.30 bahwa keterlibatan perempuan di Ndao yang merupakan pulau terluar dari Kabupaten Rote Ndao dalam musyawarah leo ada dalam persentase kecil. Keterlibatan perempuan pada musyawarah leo di Ndao pada porsi tertentu, misalnya perempuan dapat memberikan pertimbangan dan dapat mengambil keputusan pada area domestik perempuan yang bersifat teknis. 
Di Pulau Ndao telah mengalami pergeseran yang sebelumnya tidak ada keterlibatan perempuan dalam musyawarah adat, partisipasi perempuan mulai nampak, perempuan diberi kesempatan membawa acara dalam pesta perkawinan, membawa sambutan kematian, sebagai juru bicara peminangan, walaupun demikian masih tetap di dominasi oleh laki-laki. Dalam hal musyawarah leo di Ndao, laki-laki dan perempuan sama-sama berembuk, perempuan dapat mengemukakan pendapatnya, dan keputusan akhir sama-sama berembuk, akan tetapi masih di dominasi oleh laki-laki.

Berbeda dengan leo Songa, Erna Ndolu dalam wawancara pada Rabu 06 April 2016 pukul 11.0012.30 mengatakan ia merupakan salah satu pengurus leo di leo Lulu sebagai sekretaris, dalam menjalankan tugasnya kesempatan bagi perempuan dalam menyampaikan pendapat, perempuan dan laki-laki duduk pada posisi yang sama, dan keputusan akhir merupakan hasil mufakat antara laki-laki dan perempuan. Pada pembentukan badan pengurus leo Lulu, diharuskan keterlibatan perempuan dalam badan pengurus harus sama banyak dengan laki-laki. Karena adanya peran perempuan yang harus dikerjakan oleh perempuan yang tidak bisa dilakukan laki-laki. Suami ikut dalam musyawarah harus membawa istrinya, sehingga kehadiran laki-laki dan perempuan seimbang.

Partisipasi perempuan dalam musyawarah leo tergantung pada leo-leo masing-masing, sebagian kecil leo yang telah memasukan konsep gender dalam organisasi leo, akan tetapi lebih banyak yang belum memperhitungan perempuan sebagai pihak yang juga harus terlibat dan didengar pendapatnya karena orang Rote menganggap bahwa dalam urusan adat laki-laki Rote mempunyai peranan yang sangat penting, dan adat merupakan wilayah laki-laki.

Adanya peran perempuan dalam musyawarah tergantung pada kesepakatan dalam intern leo, terdapat leo yang sudah menganggap penting kehadiran perempuan dalam musyawarah leo, sehingga mengharuskan adanya keterlibatan perempuan dalam organisasi leo dan musyawarah leo, akan tetapi ada pula leo yang belum melibatkan perempuan dalam setiap aktivitas adatnya dan semua urusan adat diurus oleh laki-laki.

Dari penjelasan di atas dapat disimpulkan bahwa telah ada partisipasi perempuan dalam musyawarah leo, terlihat bahwa sebagian kecil leo memberikan kesempatan kepada perempuan untuk masuk dalam struktur organisasi leo, tetapi partisipatasinya bersifat terbatas, dan setiap pengambilan keputusan masih didominasi oleh laki-laki, perempuan hanya boleh mengambil keputusan pada hal-hal teknis. 


\section{Faktor-faktor yang Memengaruhi Partispasi Perempuan dalam Pengambilan Keputusan.}

Realitas keterlibatan perempuan dalam musyawarah leo terdapat banyak faktor yang dapat memengaruhinya sehingga setiap masukan dan pemikirannya dapat didengar, kehadiran seorang suami dalam musyawarah harus membawa serta istrinya, akan tetapi tidak semua istri yang suaminya terlibat dalam musyawarah leo mau terlibat dalam diskusi dan menyampaikan pendapat karena keterbatasan serta pengaruh budaya yang masih tertanam dalam pikiran perempuan bahwa urusan adat dan urusan publik adalah bagian laki-laki. Hanya sedikit perempuan Rote yang mempunyai keinginan besar untuk tampil ke area publik yang selama ini dianggap adalah dunia laki-laki. Berdasarkan observasi dan wawancara dengan informan faktor-faktor yang memengaruhi perempuan dalam pengambilan keputusan adalah jika seorang perempuan memiliki: tingkat pendidikan tinggi, adanya penghargaan terhadap perempuan itu, adanya penghormatan terhadap perempuan, disegani karena berpengalaman, tertua, dan memiliki karakter hidup yang patut diteladani, tidak ada sifat arogan, keibuan, tegas tetapi tidak ekstrim, terbiasa tampil di depan umum.

Dari penjelasan di atas nyata bahwa harus adanya potensi yang dimiliki seorang perempuan agar setiap masukan yang diberikan dapat dipertimbangkan dan dapat menjadi keputusan akhir dalam musyawarah leo. Perempuan harus mempunyai karakter tertentu: jika tidak memiliki karakter dan potensi di atas, perempuan Rote akan tetap pada posisi kedua dan tidak dapat turut serta dalam pengambilan keputusan dan partisipasinya dalam musyawarah leo hanya terbatas pada pemberian saran.

Perempuan Rote dalam pandangan adat Rote sudah dianggap sama dengan laki-laki, akan tetapi belum secara menyeluruh diterapkan di Kabupaten Rote Ndao, hanya sedikit perempuan yang telah diberikan kesempatan dan menerima kesempatan untuk muncul di dunia publik yang lebih banyak didominasi oleh lakilaki. Kebanyakan perempuan Rote hanya aktif dalam area domestik perempuan, partisipasi perempuan Rote pun masih kurang, artinya hanya sedikit perempuan yang masuk dalam musyawarah leo, dan berpartisipasi aktif dalam organisasi leo. Masuknya perempuan dalam musyawarah leo bersifat terbatas: perempuan hanya diberikan kesempatan untuk bicara bilamana perlu dan berurusan dengan hal-hal teknis. Pengambilan keputusan musyawarah leo masih didominasi oleh laki-laki. 


\section{Daftar Referensi}

Isnaeni. 2004. Peran Wanita dalam Politik. Jurnal Perempuan. Jakarta: Yayasan Jurnal Perempuan.

Janis, I. L., \& Mann, L. 1987. Decision making: A Psychological analysis of conflict, choice, and commitmen. New York: Free Press.

Ratoe Oedjoe, Mien. 2011. Panduan Merancang Bahan Ajar yang Adil dan Setara bagi Anak Perempuan dan Laki-laki. Kupang: Lemlit Undana.

Soh, Z, Andre dan Indrayana N. D. K. Maria. 2008. Rote Ndao Mutira Dari Selatan, Falsafah dan Pandangan Hidup Suku Rote tentang Lontar. Jakarta: Kelompok Penggerak Aktivitas Kebudayaan. 